\title{
Serrano v. Priest: A State Court's Responsibilities and Opportunities in the Development of Federal Constitutional Law
}

\author{
Kenneth L. Karst*
}

The financing of public schools is a national disgrace: First, states are carved into local school districts, some of which are wealthy and some poor. Second, the major share of school financing is tied to local taxes, usually on real property, raised within each district for the support of the district's schools. ${ }^{1}$ It follows, as it must, that rich districts can raise large revenues by levying taxes at low rates, while poor districts must levy taxes at high rates to produce even minimal revenues. Last year, in Serrano $v$. Priest, ${ }^{2}$ the supreme court of California held California's version of this grotesque school finance system unconstitutional, upholding a complaint of sclool children and taxpayer-parents that the California scheme violates both the equal protection clause of the fourteenth amendment and the analogous provisions of the California Constitution.

The volume and level of commentary on the Serrano decision attest to its importance. "Potentially," Time liedged, the decision "is the most far-reaching court ruling on schooling since Brown v. Board of Education in 1954 ...."3 Professional commentators have been somewhat less enthusiastic, but equally sure that Serrano is notewor-

* Professor of Law, University of California, Los Angeles. A.B. 1950, University of California, Los Angeles; LL.B. 1953, Harvard University. Author's note: While I have not participated in the Serrano litigation, I have been watching over the shoulders of plaintiffs' counsel from the beginning and have a godfatherly interest in the success of plaintiffs' case.

1. See J. Coons, W. Clune \& S. Sugarman, Private Wealth and Public Education 499 (1970) [hereinafter cited as PrIvate Wealtu]. This book furnished the essential arguments used by the California supreme court in its Serrano opinion. Its doctrinal analysis is summarized in Coons, Clune \& Sugarman, Educational Opportunity: A Workable Constitutional Test for State Financial Structures, 57 Calir. L. REv. 305 (1969) [hereinafter cited as Educational Opportunity].

2. 5 Cal. 3d 584, 487 P.2d 1241, 96 Cal. Rptr. 601 (1971) (Sullivan, J.) (6-1 decision). Justice MeComb dissented on the basis of the opinion of the court of appeal, Serrano v. Priest, 89 Cal. Rptr. 345 (1970).

3. TIME, Sept. 13, 1971, at 43. 
thy. ${ }^{4}$ The California supreme court consciously spoke to a nationwide audience concerning nationwide issues. ${ }^{5}$ This article is not so much an analysis of the merits of the Serrano decision ${ }^{6}$ or the quality of the opinion as it is an exploration of the role that can be played by a state supreme court in the development and application of federal constitutional law. Part I considers Serrano's doctrinal contributions to equal protection theory. Part II examines the special challenges to a state supreine court as it proinotes the development of new federal constitutional doctrine while remaining respectfully subordinate to the United States Supreme Court. Part III considers the California court's relations with the principal local audiences of its opinion: the lower courts and the state legislature.

\section{Doctrinal Contributions to Equal Protection Theory}

The doctrinal starting point for the Serrano decision is the nowfamiliar 3-part formula of the new equal protection doctrine: if a legislative classification is based upon "suspect" characteristics, and

4. See Goldstein, Interdistrict Inequalities in School Financing, $120 \mathrm{U}$. PA. L. Rev. - (1972); Note, The Evolution of Equal Protection: Education, Municipal Services, and Wealth, 7 HARv. Crv. Rights-Civ. Lib. L. Rev. 103 (1972); Schoettle, The Equal Protection Clause in Public Education, 71 CoLum. L. Rev. 1355 (1971). See also Shanks, Educational Financing and Equal Protection, $1 \mathrm{~J}$. LAw \& EDuc. 73 (1972). I have also had the benefit of seeing a draft of a provocative criticism of Serrano by Professor Paul D. Carrington.

5. Some 30 Serrano-style lawsuits have been instituted in 20 states. See N.Y. Times, Jan. 19, 1972, at $34 \mathrm{M}$, col. 8. Several such actions have proceeded to judgment and all but one have been decided in accordance with Serrano. Rodriguez v. San Antonio Ind. School Dist., 337 F. Supp. 280 (W.D. Tex. 1972) (injunction issued, but mandates stayed for two years); Van Dusartz v. Hatfield, 334 F. Supp. 870 (D. Minn. 1971) (tracking the Serrano reasoning); Hollins v. Shofstall, Civ. No. C-253652 (Super. Ct., Maricopa County, Ariz., Jan. 13, 1972) (citing Serrano and Van Dusartz, supra); Robinson v. Cahill, Civ. No. L-18704-69 (Sup. Ct., N.J., Jan. 19, 1972) (school finance system held to violate state constitution). Contra, Spano v. Board of Educ., Index No. 105-197 (Sup. Ct., Westchester County, N.Y., Jan. 17, 1972) (relying on McInnis v. Ogilvie, 394 U.S. 322 (1969), discussed in text accoinpanying notes $91-102$ infra).

There is an informal network of plaintiffs' counsel in these cases, partly coordinated by the Lawyers' Committee for Civil Rights Under Law. (My colleague Harold Horowitz, one of the counsel for the Serrano plaintiffs, has dubbed this group the "Serranoisseurs.") These counsel appear to be seeking to produce a substantial number of favorable decisions in the lower courts before the principal issue is decided by the United States Supreine Court.

6. Some of the losing parties have already expressed their approval of the decision. See L.A. Times, Aug. 31, 1971, at 1, col. 5. Two of the defendants, State Superintendent of Public Instruction Wilson C. Riles and State Controller Houston I. Fluornoy, have announced that they will not participate in any effort to seek review of the California court's decision by the United States Supreme Court. 
it concerns a "fundamental" interest, ${ }^{7}$ then it is invalid in the absence of a countervailing state interest that is "compelling." Justice Sullivan admits that the second part of the court's analysis-that education is a fundamental interest-is new in the context of wealth discrimination; the first part of the analysis-that wealth discrimination is a suspect classification-he takes as established by prior decisions of the Supreme Court. Yet, it is this first portion of the Serrano analysis, rather than the characterization of education as fundamental, that constitutes the opinion's most significant contribution to the development of constitutional doctrine. I first discuss the court's argunent that education is a fundamental interest and then the more difficult issues involved in its wealth discrimination argument.

\section{A. The Fundamental Interest in Education}

The novelty in the Serrano opinion's characterization of education as a fundamental interest is not the recognition of education's importance; it is that Serrano coupled the interest in education with wealth discrimination rather than racial discrimination. This Justice Sullivan explicitly concedes. ${ }^{8}$ The court implicitly accepts that a slidingscale principle governs new equal protection decisions: the more suspect a classification, the less fundamental need be the interest in question. ${ }^{9}$

\section{The Importance of Education}

The court had no trouble finding judicial opinions and other statements to support the proposition that education is enormously important. Such statements abound in our literature, reflecting what has become one of our national articles of secular faith. For generations education has been seen as one of the major paths for those who would be economically and socially mobile. Not only is it the gateway through which poor people enter into the middle class; it is also a gateway to the world, through which the child receives the culture. Using the kind of metaphor that comes naturally in such discussions, the court called education "the lifeline of both the imdividual and society."10 In particular, the court found that education is: essential to mamtaining equality of opportunity in a "free enterprise democracy"; universally

7. Alternately, either the suspect characteristic or fundamental interest can be so important that it alone will suffice. See McLaughlin v. Florida, 379 U.S. 184 (1964) (racial discrimination as to nonfundamental interest is invalid); Lucas v. Forty-fourth General Assembly of Colo., 377 U.S. 713 (1964) (dilution of fundamental interest in voting is invalid even though approved by general referendum).

8. 5 Cal. 3d at 604, 487 P.2d at 1255, 96 Cal. Rptr. at 615.

9. See note 7 supra.

10. 5 Cal. 3d at 605,487 P.2d at 1256, 96 Cal. Rptr. at 616. 
relevant, since everyone needs it; a government service that is sustained over a long period of time, typically 10 to 13 years; "unmatched in the extent to which it molds the personality of the youth of society"; and "so important that the state has made it compulsory-not only in the requirement of attendance but also by assignment to a particular district and school."11 In addition, the court said that education is fundamental because, like voting, education is

crucial to participation in, and the functioning of, a democracy. Voting has been regarded as a fundannental right because it is "preservative of other basic civil and political rights . . .."12

Education is thus fundamental partly because it is instrumental to the achievement of so many other goals and rights.

But voting and education by no means exhaust the catalogue of interests that are important because they are instrumental. Employment, for example, seems fundamental in this same instrumental sense. ${ }^{13}$ Similarly, the interest in access to housing is vitally instrumental to a whole complex of social and economic goals, includingsince children are assigned to schools on the basis of geographic zones of residence-good education. In fact, the ownership of a house in a "good" neighborhood is the preeminent symbol of arrival in the middle class, and the symbolism of social status is at the heart of the issue of equality, as today's black revolution reminds us. ${ }^{14}$

It should not be surprising that virtually any interest of importance can be conceived in such instrumental terms. It would be surprising, indeed, if this were not so, given the complicated interrelationships that characterize our mcreasingly interdependent society. While the short-term prospects for expanding the list of fundamental interests in wealth discrimination cases seem dim, ${ }^{15}$ it appears safe to predict that

11. Id. at $609-10,487$ P.2d at 1258-59, 96 Cal. Rptr. at $618-19$.

12. Id. at $607-08,487$ P.2d at 1258, 96 Cal. Rptr. at 618, quoting Reynolds v. Sims, 377 U.S. 533, 562 (1964).

13. Justice Field so argued in the Slaughter-House Cases [83 U.S. (16 Wall.) 36,83 (1872) (Field, J., dissenting)] as did a majority of the Court in the series of cases typified by Lochner v. New York, 198 U.S. 45 (1905).

14. Frank Michelman makes the point neatly, in terms that are obviously applicable to the institutions of Jim Crow:

The evil of a relative deprivation (read "discrimination" or "nonevenhandedness") is psychic or moral; it consists of an affront; it is immediately injurious insofar as resented or taken personally, and consequently imjurious insofar as demoralizing.

Michelman, On Protecting the Poor Through the Fourteenth Amendment, Foreword to The Supreme Court, 1968 Term, 83 HARv. L. Rev. 7, 49 (1969).

15. See, e.g., James v. Valtierra, 402 U.S. 137 (1971); Dandridge v. Wilhams, 397 U.S. 471 (1970). Professor Schoettle, supra note 4, at 1405, suggests that these two decisions cast doubt on the validity of the theory of the Serrano opinion. But the California court carefully noted its awareness that pre-Serrano wealth discrimination decisions in the Supreme Court lad been limited to cases involving voting rights 
today's judicial reluctance will give way to tomorrow's validation of claims to equality that are already being heard. The doctrinal focus may be on "minimum protection"16 or equality, but the results of the cases are unlikely to be significantly affected by the choice between those two viewpoints. Not even an "equal protection theorist"17 would suggest an affirmative governmental obligation to level all aspects of the society's allocation of benefits and burdens. Selection of "fundamental" interests must be made, even in the name of equality, so that the minimum-protection concept is inescapably a part of any equalizing process. Conversely, in an area like education, where "the minimum is significantly a function of the maximum,"18 the minimum-protection theorist will necessarily be concerned with issues of relative deprivation in determining which wants are those "just wants" the satisfaction of which is included in the state's minimum constitutional duty. ${ }^{10}$

For whatever reason, the Serrano opinion speaks not of minimum protection but of equal protection; it is the relative deprivation of education that gives poor school districts their claim. Still, Serrano imvolved not merely relative deprivation, but deprivation with respect

and rights in the criminal process [5 Cal. 3d at 604, 487 P.2d at 1255, 96 Cal. Rptr. at 615] and carefully articulated its extension of the doctrine to education-which was not involved in either Dandridge or Valtierra.

16. Michelman makes the argument that most of the new equal protection cases are reconcilable with a theory of "minimum protection" against the failure to satisfy certain "just wants." He further argues that this theory, which rests not so inuch on the idea of equality as it does on analogies to substantive due process, is superior to an equality theory in meeting the essential needs of poor persons in a society that continues to be dominated by a market economy in which goods and services cost money. See Michelman, supra note 14, passim.

17. This is Michelman's phrase describing those writers who emphasize an equality theory (or strategy) in attacking the constitutionality of various forns of relative deprivation visited upon the poor. In particular, he applies the term to Coons, Clune, and Sugarman; see note 1 supra. Michelman, supra note 14, at 53.

18. See Michelman, supra note 14, at 58.

19. Even the abolition of a state's public schools, which seems a good case for testing differences between the minimun-protection and equal protection theories, involves questions of relative disadvantage, whichever theory is used. If such an abolition violates a minimum-protection principle, the reason surely is not education's intrinsic importance but rather the relative advantage that the abohtion would give to the privately schooled children of wealthy families and to the children who receive public education in other states in our geographically mobile national society. So, also, the application of a minimum-protection theory to the interest in voting would turn on questions of relative advantage. Voting is protected under a ininimumprotection theory (an equal protection theorist would say, voting is fundainental) largely because it permits competitive participation in the political marketplace. Thus, the dilution of a citizen's vote-a relative deprivation of voting strength-is unconstitutional. See Reynolds v. Sins, 377 U.S. 533 (1964). The early criminal-process wealth-discrimination cases [e.g., Douglas v. California, 372 U.S. 353 (1963); Griffin v. Illinois, 351 U.S. 12 (1956)] cannot be explained in minimum-protection terms, but the reason is only that the Supreme Court assumed in those cases that there was no "minimun" constitutional right to an appeal. 
to an interest that the court declared fundamental. What is left unspecified is the content of this fundamental interest in education. The resulting vagueness in the boundary lines of the Serrano reasoning permits the opinion to be read broadly. Thus, while the California court has told us that education is fundamental, it has not told us whether there is some level of spending on education beyond which further increments are no longer fundamental. Suppose, for example, that the state were to make available to each school district $\$ 1,200$ per year per student-roughly the level at which Beverly Hills was spending when the Serrano complaint was filed. ${ }^{20}$ Wealthy districts would still have the capacity to spend more on schooling, and the exercise of that extra spending capacity might well be unconstitutional. Certainly such additional spending would amount to wealth discrimination, and, arguably, there would be discrimination as to an interest that is fundamental. Nothing in the Serrano opinion detracts from the generality of its statements about wealth discrimination in education. Moreover, history teaches that what is now thought lavish may be viewed tomorrow as a minimum level of support; thus, the equal protection argument rests not only on distinctions between rich and poor, but also on the capacity of an increasingly affluent nation to support education. Both the relative-deprivation and the minimum-protection approaches to equal protection will be useful in deciding this kind of issue.

\section{Beyond Education: Equality in Other State Services?}

The court took some pains to deny that its reasoning was automatically transferable from education to other kinds of public services such as fire and police protection, hospitals, or recreational facilities. The "equal sewer problem"21 sinuply was not before the court, and it expressly "intimated no views on other governmental services . . . .,22 Education's "uniqueness among public activities," the court said, was enough to justify application of the "strict scrutiny" test of the new equal protection cases. ${ }^{23}$ And yet, the court adds a long, tantalizing footnote ${ }^{24}$ citing with approval a recent Fifth Circuit decision focusing the same strict scrutiny on a case of racial discrimination in a Mississippi city's provision of street paving and lighting, sewers, water mams, dramage, and fire hydrants. ${ }^{25}$ Although the racial element made that case easy, the court's footnote goes on to quote a portion of the Fifth Circuit's opinion suggesting that wealth discrimination as to those serv-

20. 5 Cal. $3 d$ at $600 \mathrm{n} .15,487$ P.2d at $1260 \mathrm{n} .15,96 \mathrm{Cal}$. Rptr. at $612 \mathrm{n} .15$.

21. Educational Opportunity 386.

22. $5 \mathrm{Cal}$. 3d at $614,487 \mathrm{P} .2 \mathrm{~d}$ at $1262,96 \mathrm{Cal}$. Rptr. at 622 .

23. Id. at 614,487 P.2d at $1263,96 \mathrm{Cal}$. Rptr. at 623 .

24. Id. at $641 \mathrm{n} .31,487$ P.2d at 1262 n.31, 96 Cal. Rptr. at 622 n.31.

25. Hawkins v. Town of Shaw, 437 F.2d 1286 (5th Cir. 1971). 
ices might also be unconstitutional. The court thus gives with one hand, while taking away with the other in a footnote that is nothing less than an invitation to the poverty bar to litigate concerning other public services.

This is not the place to pursue the obvious analogies that led the Serrano defendants to express appreliensions that a decision against them would require the invalidation of wealth discrimination in the provision of other governmental services. ${ }^{26}$ The Serrano court did what comes naturally to a court breaking important new ground: sufficient unto the day was the task immediately at hand. Tomorrow, of course, the courts will be pressed to extend Serrano's reasoning to all those other public services. Some writers, even those who emphasize relative deprivation as the heart of the equal protection argument in the context of education, have called such an extension "almost, but not quite, inconceivable."27 And one of the principal reasons for the minimum-protection approach to protecting the poor appears to be the wish to stop short of such a thoroughgoing extension-to articulate a response, as Frank Miclielman says, to the question, "Why education and not golf?"28

Coons, Clune, and Sugarman, the authors who almost cannot conceive of the extension of Serrano-style reasoning to the full range of public services, argue against such an extension on grounds of judicial restraint. Judges are properly uncomfortable, they say, in the absence of judicially manageable standards for decision. Furtherunore, judicial invalidation of legislation should be kept at a minimuin to avoid preempting the legislature froin its role. Lastly, these writers argue that a court must maintain enough of a political consensus to ensure that its decrees are enforced. ${ }^{29}$

The Serrano case, they argue, ${ }^{30}$ meets these tests, while extensions of Serrano to other mumicipal services would not ineet them; but their arguments are unconvincing. First, they say that education is unique because a manageable standard is available: "The quality of public education may not be a function of wealth other than the wealth of the state as a whole." ${ }^{31}$ But any number of other terns taken from 622.

26. Noted by the court at $5 \mathrm{Cal} .3 \mathrm{~d}$ at $614,487 \mathrm{P.2d}$ at $1262,96 \mathrm{Cal}$. Rptr. at

27. Private Wealth 414; Educational Opportunity 387.

28. Michelman, supra note 14 , at 59 . See the discussion of the "equal sewers problem" in Note, The Evolution of Equal Protection, supra note 4, at 154-68.

29. Prvate Wealth 290-94.

30. Brief of Stephen D. Sugarman, The Urban Coalition, The National Committee for the Support of the Public Schools, and John E. Coons as Amici Curiae at $22-43$.

31. Private Wealth 304; Educational Opportunity 311. 
the list of public services provided by state and local governments might be substituted for the word "education." Second, these writers argue that the invasion of the legislature's policy domain is justified with respect to wealth discrimination in education, because the parents of children in poor districts ${ }^{32}$ never can hope for the political strength to overcome the existing structure of privilege in education. Therefore, "[b]efore the democratic process can assemble a new consensus . . . the principle of Ricl District-Poor District must perish."33 Again, education is not unique, because the same argument is equally plausible in the context of garbage collection or street lighting. Finally, Coons, Clune, and Sugarman note that their formula does not command any particular solution for financing education but leaves the legislature leeway in order to minimize the likelihood of defiance. Are we not entitled to expect a similar sensitivity when the same court comes to deal with a poor district's complaint that its streets are unpaved?

In differentiating education from other governmental services, Coons, Clune, and Sugarman advance the arguments adopted almost verbatim by the Serrano court to summarize its conclusion that education is a fundamental interest: Education is the gateway to full participation in "free enterprise democracy"; it is compulsory and universally relevant; all benefit from it; is continuous over a long period in virtually everyone's life; and it crucially molds the personality of the young person. In contrast, they say this about other public services:

If we encourage people to become rich, we should be slow to prohibit their living together and taking advantage of their wealth by putting together a desired package of municipal services; nor should we confuse the issue by conjuring up visions of rat bitten slum children suffocating in garbage and adapting to life on inadequately protected streets. We can and perhaps will solve these problems of physical living standards with'a minimum level of public services, whether or not the Court can intelligibly matcli the nnoral imperative for that minimum with a constitutional standard..$^{34}$

The visions mentioned, however, are not conjured; they are real for those who live them. It is therefore valid to ask why, if the rich cannot put together their desired packages of education, the rich can do so

32. Coons and Sugarman, as amici curiae, made a broader argument about political disadvantage: all children are disadvantaged, since they do not vote. Brief of Stephen D. Sugarman, The Urban Coalition, The National Committee for the Support of the Public Schools, and John E. Coons as Amici Curiae at 25. The court did not allude to this argument. The Sugarman-Coous brief contains the best short analytical description of the workings of the California school finance system that I have seen. Id. at 4-22.

33. Educational Opportunity 325; see PrIVATE Weatth 293.

34. Educational Opportunity 387. 
in other areas of public services-or whether growing up with an abundance of rats and a scarcity of physical security may not mold a child's personality and undermine his participation in "free enterprise democracy." The court's footnote in Serrano properly suggests that the Constitution's concern about wealth discrimination does not stop as the child leaves the schoolground to walk down a sidewalk that is dangerous because it is broken, unlighted, filthy, and unpatrolled.

Why education and not golf? The minimum-protection approach is seen in its best light if we conceive of a state that provides neither schools nor golf courses. The minimum protectionist would argue that the state must provide scliools but may constitutionally leave golf to the forces of the market, thus limiting golf to those who can pay the fees at public courses or afford to join private clubs. So far, few equal protectionists would disagree, for golf is not considered a fundamental interest and seems unlikely to be considered one very soon. Even here, however, two cautions are in order. First, the contrast between education and golf is lieightened by the breadtli of one term and the narrowness of the other. ${ }^{35}$ Suppose the issue were instead posed, why recreational facilities and not a inovie projector for each classroom? In the affluent, leisure-oriented future so confidently predicted by many, it is not liard to conceive that the interest in some recreational facilities may come to be regarded as fundamental. Second, it is one thing to say that the state need not build golf courses at all, but if a state does build golf courses, can it constitutionally locate them only near its wealthier residential zones?

These questions about fundamental interests could hardly have been expected to find answers in the Serrano opinion. That opinion goes quite far enough im bringing education, however vaguely defined, into the "inner circle" 36 of interests that are fundamental for purposes of equal protection analysis. "Once loosed," Archibald Cox wrote, "the idea of Equality is not easily cabined." 37 The Supreme Court's recent efforts notwithstanding ${ }^{38}$ Professor Cox's implied prediction is sound. In Serrano the court lias made a crucial contribution to the progressive extension of equal protection doctrine to new subject areas,

35. Cf., e.g., Uphaus v. Wyman, 360 U.S. 72 (1959) (one witness' interest in maintaining secrecy about Communist Party associations balanced against the security of the nation).

36. The phrase belongs to Coons, Clune, and Sugarman. See Private Wealth 339-93.

37. Cox, Constitutional Adjudication and the Promotion of Human Rights, Foreword, The Supreme Court, 1965 Term, 80 HARv. L. REv. 91 (1966).

38. See Gordon v. Lance, 403 U.S. 1 (1971); James v. Valtierra, 402 U.S. 137 (1971); Labine v. Vincent, 401 U.S. 532 (1971); Evans v. Abney, 396 U.S. 435 (1970). 
a contribution that seems certain to bear fruit when the winter that began in 1970 is over.

\section{B. Wealth Discrimination As a Suspect Classification}

The Serrano complaint alleged a number of inequalities that resulted from California's system of school financing. First, and most important, was the inequality that results because the finance system ties the quality of education to district wealth. Other types of inequality were alleged: the quality of education depends on the geographical accident of school-district residence; the system fails to take account of children's educational needs; the system perpetuates the inequalities of services and facilities that result from past inequitable allocation of state resources; the system results in a relatively inferior educational opportunity for children who are black, or have Spanish surnames, or are members of other minority groups; and the financing system requires people like the parent-taxpayer plaintiffs to pay higher tax rates than do taxpayers in other relatively wealthy districts in order to receive for their children the saine or lesser educational opportunities. Justice Sullivan devoted almost all of his attention to the first point; wealth discrimination was held to be enough, in combination with the characterization of education as a fundamental interest, to require apphication of the compelling-state-interest test of constitutionality-and the state's asserted interests did not pass that test.

The defendants made three attacks on the proposition that the California school finance system amounted to wealth discrimination. First, they pointed to the state's aid programs, arguing that "basic aid" provided flat grants to districts on the basis of an equal amount per pupil and that "equalization aid" distributed additional funds according to a plan that gave the greatest benefits to poor districts. For this the court had an easy answer:

State funds constitute only one part of the entire school fiscal system. . . . [State aid] partially alleviates the great disparities in local sources of revenue, but the system as a whole generates school revenue in proportion to the wealth of the individual district. ${ }^{39}$

Next, defendants argued that the assessed valuation per pupil and the expenditure per pupil were not reliable indexes of either the wealth of a district or that of its residents. ${ }^{40}$ Instead, they said, the best index of district wealth is the total assessed valuation in the district. The court answered that the only meaningful measure of district wealth in this context is the ratio of resources to pupils, since this

39. 5 Cal. $3 d$ at 598, 487 P.2d at 1250-51, 96 Cal. Rptr. at 610-11.

40. Id. at 599, 487 P.2d at $1251,96 \mathrm{Cal}$. Rptr. at 611 . 
ratio determines how much the district can spend per child. Falling back to the next trench, the defendants argued that per-child spending cannot be taken as an index of wealth, since spending is determined not only by the assessed value of the taxed property but also by the tax rate. The court's response is profoundly significant:

Obviously, the richer district is favored when it can provide the same educational quality for its children with less tax effort. ${ }^{41}$

Finally, defendants argued that a district's wealth did not necessarily reflect the wealth of families hiving in the district. The principal response of the court ${ }^{42}$ was that classification according to district wealth is no less invalid than classification according to family wealth. The fortuitous presence of commercial or industrial property in a district is irrelevant in determining the allocation of educational funds. ${ }^{43}$

Alternatively, the defendants argued, even assuming that the school finance system does discriminate on the basis of wealth, the system is not invahid in the absence of a showing of purposeful discrimination. The court's answer was that none of the wealth classifications previously held invalid by the Supreme Court involved purposeful discrimination. What matters is a discriminatory effect, not the intention to create a disadvantage based on relative poverty. Moreover, the court argued, the discrimination in the California school finance system is not inerely de facto, since the state estabhished the scheine that rests school financing so largely on district wealth, drew the district lines, and adopted or authorized zoning laws and other controls that influenced the location of residences and commercial and industrial buildings. ${ }^{44}$ But even if the wealth discrimination were assumed for argu-

41. Id. Beverly Hills, while taxing itself at a school tax rate of $\$ 2.38$ per $\$ 100$ of assessed valuation, was able to spend $\$ 1,232$ per child in 1968-69. Baldwin Park, also in Los Angeles County, levied its tax at the rate of $\$ 5.48$ per $\$ 100$ of assessed valuation, in order to be able to spend $\$ 577$ per pupil. The court explicitly relied on these figures in this portion of its opinion. Id. at $601,487 \mathrm{P.2d}$ at $1252,96 \mathrm{Cal}$. Rptr. at 612.

42. Id. at $600-01,487$ P.2d at 1252, 96 Cal. Rptr. at 612 . Additionally, the court noted that since plaintiffs had alleged a positive correlation between district wealth and resident wealth, the fact inust be taken as true for the purposes of testing the sufficiency of the complaint. Id. at 601, 487 P.2d at 1252, 96 Cal. Rptr. at 612. In view of the court's other response, noted in the text, this factual issue probably will not be significant upon trial of the case.

43. Id. at 601,487 P.2d at 1252-53, 96 Cal. Rptr. at 612-13.

44. Here the court quotes a paragraph from Michelman:

[The states] have determined that there will be public education, collectively financed out of general taxes; they have determined that the collective financing will not rest mainly on a statewide tax base, but will be largely decentralized to districts; they have composed the district boundaries, thereby determining wealth distribution among districts; in so doing, they have not only sorted education-consuming households into groups of widely varying average wealth, but they have sorted non-school-using taxpayers-households and others-quite unequally among districts; and they have made education 
ment to be de facto, the court added, defendants could not draw support from the school segregation cases, because a prior California supreme court decision held de facto racial segregation invalid. ${ }^{45}$

The court's responses to these various arguments provide a rich lode for commentators. I shall pursue four of its veins: (1) the extension of wealth discrimination analysis beyond the protection of indigents to the protection of the "nonpoor",46 (2) the relation between de facto and de jure wealth discriminations in education; (3) the significance of Serrano for the "benefit" and "ability to pay" theories of public finance, in the context of education; and (4) the relation of the court's discussion of geographical discrimination to its primary focus on wealth discrimination.

\section{Protecting the Nonpoor}

The court's discussion of wealth discrimination begins with citations to the leading Supreme Court decisions in the area. As Justice Sullivan notes elsewhere in his opinion, these decisions dealt with wealth classifications that conditioned access to the franchise ${ }^{47}$ and to certain rights of defendants in criminal cases. ${ }^{48}$ The emphasis in all these prior opinions lias been on discrimination against the poorpersons who cannot afford to pay a small poll tax as a condition on voting or persons who cannot afford a trial transcript or appellate counsel. To the extent that wealth discrimination has been held by the Supreme Court to imply a suspect classification, the disadvantaged group in question has been identified as persons who are indigent.

Although Serrano opinion refers to these earlier Supreme Court decisions as involving burdens that "fell more heavily on the poor," or the burdens of "poverty" the California school finance system's effects on "the indigent"

compulsory.

Michelman, supra note 14, at 50, quoted in 5 Cal. $3 \mathrm{~d}$ at $603 \mathrm{n.19}, 487$ P.2d at 1254-55 n.19, 96 Cal. Rptr. at 614-15 n.19. Michelmau included this passage to show how the typical school finance system "transcends a mere payment requirement." The origimal passage concludes with this phrase, which, significantly, the California court did not quote: "- though, perhaps when all is said, the transcendence will seem marginal." Id. For discussion of Serrano's implications for payment requirements in education, see text accompanying notes 72-77 infra.

45. Jackson v. Pasadena City School Dist., 59 Cal. 2d 876, 382 P.2d 878, 31 Cal. Rptr. 606 (1963).

7.

46. This term comes from Coons, Clune, and Sugarman. See Prrvate Wealth

47. Harper v. Virginia State Bd. of Elections, 383 U.S. 663 (1966).

48. Tate v. Short, 401 U.S. 395 (1971); Williams v. Illinois, 399 U.S. 235 (1970); Anders v. California, 386 U.S. 738 (1967); Douglas v. California, 372 U.S. 353 (1963); Griffin v. Illimois, 351 U.S. 12 (1956).

49. 5 Cal. $3 \mathrm{~d}$ at 602,487 P.2d at 1253, 96 Cal. Rptr. at 613.

50. Id. at 610,487 P.2d at 1259, 96 Cal. Rptr. at 619. 
it is plainly true that Serrano rests not so much on a poverty theory as on a theory of relative educational disadvantage. A poor child who lives in the shadow of a factory may live in a relatively wealthy school district, precisely because of the presence of industrial property. A child of a middle class family may live in a poor school district. Thus, the impact of Serrano on these two children will be to deny the poor child the advantage of hiving in a rich district and to reheve the middle class child of the disadvantage of living in a poor district. If the relevant measure of equality in school financing is per-pupil spending capacity, then some pupils can be characterized as "poor" with respect to public education, whatever may be their other indicia of economic status.

An anomaly lurks in this reasoning. To the extent that the new equal protection doctrine of "strict scrutiny" rests on the idea of protecting disadvantaged groups, it seems odd to measure relative disadvantage in terms of the very service or resource being allocated by the state. If, for example, all school funds were dispensed by the state and dispensed so that some districts could spend twice as much on schools as others, it would be circular for us to discuss the problem in terms of suspect classifications. We should say, not that the allocation scheme is suspect because it disfavors a disadvantaged group, but that it violates the traditional rational-basis equal protection standard since it lacks any discernible justification. Perhaps Justice Sullivan liad this in mind when lie suggested that one's address should not determine the quality of his child's education any nore than it determines the weight of his vote. ${ }^{51}$ Thus, the theory of Serrano is that not only individual poverty but also poverty in the public educational resources in one's district places a person in a disadvantaged group. Yet every state prograin has a differential impact on individuals. If we can conceive of public education poverty, then we can also conceive of street lighting poverty, influenza immunization poverty, or even, with a wink at Lochner's ghost, economic liberty poverty. ${ }^{52}$

The justices who concurred in Serrano would surely call the latter suggestion frivolous. In the first place, the Serrano plaintiffs had alleged a positive correlation between family wealth and district wealth, ${ }^{53}$ so that Serrano's principle coincides, on the whole, with a

51. Id. at $613,487 \mathrm{P} .2 \mathrm{~d}$ at $1262,96 \mathrm{Cal}$. Rptr. at 622 .

52. The new equal protection doctrine lends itself to such speculations. See Brest, Interdistrict Disparities in Educational Resources, 23 StaN. L. Rev. 591 (1971); Karst, Invidious Discrimination, 16 U.C.L.A.L. Rev. 716 (1969).

53. See note 42 supra. Goldstein, supra note 4 , at -, argues that the data do not support this allegation, at least as a general nationwide proposition. In Rodriguez v. San Antonio Ind. School Dist., 337 F. Supp. 280 (W.D. Tex. 1972), the court found such a correlation in Texas. 
principle based on discrimination against the poor. More importantly, if the "new equal protection" is a doctrinal system for protecting classes that are in some sense permanently disadvantaged in the political process, such as racial minorities, aliens, and the poor, a respectable analogous argument can be made on behalf of school districts that are relatively poor. ${ }^{54}$ Moreover, the court's elaborate discussion of education's fundamental nature is itself a limitation on the extension of the Serrano reasoning to such fanciful contexts as economic regulation. ${ }^{55}$

Perhaps it is the fundamental nature of education that is the critical point. If the interest invaded is sufficiently fundamental, the legislative classification may be imvalid even though it does not fall agamst a group that was previously disadvantaged. The reapportionment cases are consistent with such a theory; ${ }^{56}$ there, the only disadvantage considered by the Supreme Court was the disadvantage inherent in the allocation of voting strength through the drawing of district lines, which was the very legislation whose validity is bemg tested. In Serrano, the interest in education is sufficiently important to justify strict judicial scrutiny of any inequality imposed by the state's fimancing scheme, whether or not the mequality works against a previously disadvantaged group such as the poor. The implications of this approach for the new equal protection doctrine are, of course, to minimize the effort to find discriminations against the poor and to maximize the effort to identify interests that are fundamental-or, im minimumprotection language, to identify basic human wants that are "just wants."

\section{De Facto and De Jure Wealth Discrimination}

In the context of school racial imbalance, the California supreme court has previously recognized the difficulty of categorizing racial segregation as either purposeful or not, de jure or de facto. ${ }^{57}$ In a Serrano footnote, the court made the same observation and therefore declined to decide whether "the complex configuration of public and private decisions which has resulted in the present allocation of educational funds" should be characterized as de jure or de facto. ${ }^{58}$ Nevertheless, the court had no trouble finding enough governmental action to reject the defendants' argument that the wealth discrimination in Serrano was, at most, de facto. ${ }^{59}$ The district poverty that produces

54. See Private Wealth 374.

55. But see text accompanying note 25 supra.

56. Especially Lucas v. Forty-fourth General Assembly of Colo., 377 U.S. 713 (1964). See note 7 supra.

57. See San Francisco Unified School Dist. v. Johnson, 3 Cal. 3d 937, 956-57, 479 P.2d 669, 680-81, 92 Cal. Rptr. 309, 320-21 (1971).

58. 5 Cal. 3d at 604 n.20, 487 P.2d at 1255 n.20, 96 Cal. Rptr. at 615 n.20.

59. Id. at 603,487 P.2d at 1254, 96 Cal. Rptr. at 614. 
a reduced school spending capacity, the court argued, is the creature of the state-established district boundaries and controls for the use of land.

As both the Coons, Clune, and Sugarman group ${ }^{00}$ and Michel$\operatorname{man}^{61}$ have remarked, there is soinething especially obnoxious about a wealth classification that is expressly ordained by state law. The poverty that prevented people from paying the poll tax in Harper, like the poverty that prevented the hiring of appellate counsel in Douglas or the purchase of a transcript in Griffin, was not the result of direct state action; the state laws in those cases were neutral, applicable alike to rich and poor. The result of those decisions was the doctrinally novel idea that it is sometimes unconstitutional for the state to treat unquals equally. ${ }^{62}$ Serrano, in comfortable contrast, rests on the more traditional notion that it may be unconstitutional to treat equals unequally. What is interesting about the Serrano opinion's treatment of these matters is not its recognition of the state's obvious role in creating the public education poverty of some school districts, but its suggestions that look in the direction of affirmative state obligation.

Suppose, for example, that the state were to abandon all its support for schools. If local communities were permitted to establish their own schools, the resulting interdistrict disparities in school spending capacity would approximate those held unconstiutional in Serrano ${ }^{63}$ and would almost certainly suffer the same fate. Justice Sullivan said:

Plaintiff clildren liave alleged facts showing that the public school financing system denies them equal protection of the laws because it produces substantial disparities among school districts in the amount of revenue available for education..$^{64}$

Similarly, in the hypothetical case, by permitting its local subdivisions to establish public schools the state would perpetuate wealth discrimmation in the furnishing of public education. But now suppose that the state not only abandons statewide programs relating to public scliools, but also forbids cities or other subdivisions from establishing public schools. Now there is no wealth discrimination in public education, for there is no public education at all. The result would be to place education among those services that are allocated by a market

60. Private Wealth 374.

61. Michelman, supra note 14, at 28-29. But Michelman regards a "payment requirement" as entirely valid for anything beyond "just wants" or "fundamental interests." Id. at 29.

62. See Karst \& Horowitz, Reitman v. Mulkey: A Telophase of Substantive Equal Protection, 1967 SuP. CT. Rev. 39, 57-65.

63. In fact, the disparities among districts would be even greater than those produced by the existing California system, since the state's "equalization" aid would be withdrawn. See text accompanying notes 110-12 infra.

64. 5 Cal. 3d at 618, 487 P.2d at 1265, 96 Cal. Rptr. at 625. 
mechanism. To dress the situation in new equal protection clothes, we might say that there would be de facto wealth discrimination in education.

Serrano does not hold that such de facto wealth discrimination is unconstitutional, but two hints are dropped. First, Justice Sullivan begins his discussion of the defendants' argument about de facto wealth discrimination by noting that the United States Supreme Court's wealth discrimination decisions have rested on the effects of "unintentional" classifications, the primary impact of which fell on the poor. ${ }^{65}$ Justice Sullivan continues:

For example, several cases have held that where important rights are at stake, the state has an affirmative obligation to relieve an indigent of the burden of his own poverty by supplying without charge certain goods or services for which others must pay. ${ }^{66}$

Considering the importance attached to education in the California court's treatment of the fundamental-interest point, it is by no means farfetched to suggest that the state cannot constitutionally leave poor people's education to the market's tender mercies. The second hint arises out of the court's response to the defendants' argument that since the Supreme Court has never held de facto racial segregation to be invalid, there is nothing constitutionally objectable about de facto wealth discrimination. Even assuming, the court said, that the school finance wealth discrimination is de facto and not de jure,

this court eight years ago held [de facto racial] segregation invalid, and declared that school boards slould take affirmative steps to alleviate racial imbalance, however created. ${ }^{67}$

The word "affirmative" appears in each of these discussions, and its choice does not appear to be accidental.

Staggering implications can be found in this language-some so staggering that it is certain they were not intended. For exainple, if the state were to provide $\$ 2,000$ per year per student for education, in theory even that level of spending would not be enough if it could be shown that somewhere in the state some luxurious private school were spending more. No such implications need be drawn from Serrano; nor should we expect the demise of private schools as a constitutional necessity in the predictable future. ${ }^{88}$ Even a principle of affirmative

65. Id. at 602,487 P.2d at $1253,96 \mathrm{Cal}$. Rptr. at 613.

66. Id. (emphasis added).

67. Id. at 604,487 P.2d at 1255,96 Cal. Rptr. at 615 (emphasis added).

68. Since Pierce v. Society of Sisters [268 U.S. 510 (1925)], it has been assumed that parents have a constitutional right to send their children to private, rather than public, schools if they choose to do so. In a Serrano-type complaint filed after Serrano was decided, plaintiffs allege as one cause of action their entitlement to state support of their attendance at private schools. Complaint at 8-12, Jelliffe v. Berdon, Civ. No. (D. Conn., filed Dec. 30, 1971). 
governmental obligation to provide education has its limits, whether we speak in terms of minimum protection or fundamental interests, as we liave seen. ${ }^{69}$

There is no way to avoid such a limitation of the state's duty, even in the field of education. The difficulty lies in what William Klein calls the "violin lessons problem."70 Wealthy families can always buy special educational services for their children that will exceed the offerings of even the most fully supported school. The distinction between the constitutionally required minimum of educational services and those services that can be left to the pricing mechanism is, like the planet Pluto, undeniably there, but it is difficult to discern without artificial aids. The movement of other constitutional bodies tells us that the line must fall somewhere between basic instruction in mathematics and a guaranteed annual trip to Paris, but plotting that line with precision would be an uncomfortable task for judges. We should therefore expect courts to be satisfied, at least for a time, with what appear to be good faith legislative efforts to secure an adequate, generously defined minimum education for every child. Serrano invites such good faith legislative experimentation. ${ }^{71}$

\section{The "Benefit" and "Ability to Pay" Approaches to School Finance}

Without abandoning its ties to education, the state could turn education over to the market mechanism by charging a tuition fee for public schooling. A similar "benefit" theory of public finance justifies, for example, gasoline taxes that pay for highways by charging users in proportion to their use. But education is, of course, different. To tell the poor that the public scliools are the gateway to social and economic mobility, but that the gateway is a toll gate open only to those who can pay, would be cruel and unjust. Serrano strongly suggests that such a tuition scheme would also be unconstitutional. ${ }^{72}$

69. See text accompanying notes 16-19 supra.

70. My colleague Klein has used this expression as we have struggled with Serrano's implications over lunch and coffee.

71. See text accompanying notes 148-63 infra.

72. I assume that school attendance would not be coinpulsory under such a system. The reasoning in the text appears equally apt for state-operated higher education, but it is entirely possible that a conrt might stop short of establishing such a constitutional requirement. Douglas v. California [372 U.S. 353 (1963)] was hinited to the case of the first appeal, presumably for reasons that have less to do with easily articulated principle than with a practical sense of proportion. Just as a second appeal, or other post conviction relief, may not be thought sufficiently fundainental to bring into play the new equal protection, so higher education might be called nonfundamental. But when a majority of high school graduates go on to higher studies, there is little justification for stopping the reach of equal protection at the 
The defect the court found in California's school finance scheme was its linking of educational quality to district wealth; a tuition system links educational quality to family wealth, a classification that is even more suspect. Since a user tax on school-using families is an unconstitutional discrimination against the poor, then other sources of revenue must be found. The chief alternatives rest on the taxpayers' ability to pay. ${ }^{73}$

Because so much of the Serrano opinion is devoted to discussion of the uneven distribution of school funds, it is possible in reading the opinion to miss its essential point about school taxation: a system that produces equal school revenues only through unequal school tax efforts is unconstitutional. The court's argument, based upon the judicially noticed interdistrict disparities in taxing capacity, was:

Obviously, the richer district is favored when it can provide the same educational quality for its children with less tax effort. Furthermore, as a statistical matter, the poorer districts are financially unable to raise their taxes high enough to match the educational offerings of wealthier districts. ${ }^{74}$

By "tax effort," the court clearly means to refer to the property tax rate; a district that is "financially unable" to raise further school taxes is a district in which the school tax rate is already high.

Imagine two school districts of equal population, Wealthy and Poor. In Wealthy each house has a value of $\$ 50,000$, and the school tax rate is 2 percent. In Poor, each house has a value of $\$ 20,000$, and the school tax rate is 5 percent. Each district can spend the same amount per child, but nonetheless, Serrano holds this scheme unconstitutional-assuming that the amount of spending affects the quality of education. ${ }^{75}$ Next, suppose that the state takes over the whole process of school financing, providing the same amount per child throughout the state. Instead of collecting a statewide property tax at a set percentage rate, however, the state levies a statewide school tax of $\$ 1,000$ per house. The new scheme iniposes exactly the same tax burden on property owners in Wealthy and in Poor as were produced in the scheme held invalid in Serrano. I think it extremely unlikely that the supreme court would reach a different result in such a case, for

12th grade. See Grant, Tuition at the State College Level: Denial of Educational Opportunity, 5 Clearinghouse Rev. 634 (1972).

73. The sales tax fits only uneasily into either the user-tax or ability-to-pay principle. Its use to finance education in part probably is not foreclosed by Serrano, but total or even primary rehance on the sales tax for this purpose would seem to raise the spectre of wealth discrimination.

74. $5 \mathrm{Cal} .3 \mathrm{~d}$ at $599-600,487$ P.2d at 1251, $96 \mathrm{Cal}$. Rptr. at 611. See text accompanying note 41 supra.

75. See text accompanying notes $128-40$ infra. 
the tax effort of Wealthy would continue to be less than half the effort of Poor. ${ }^{76}$

Implicit in the court's statements about tax effort is a major new constitutional theory: If the fundamental interest in education must be satisfied by the state on a basis that does not discriminate against the poor, and if the measure of discrimination is relative tax effort, the court has gone some distance toward a constitutionally compelled ability-to-pay system of school taxation. This suggestion will not astonish a minimum-protection theorist. Once a benefit or payment system is abandoned, even partially, the government is giving a form of subsidy, and a subsidy assuring the poor minimum levels of support for certain fundamental interests obviously must be financed by those who are not poor. Thus, Serrano means not only that the state must subsidize education for children in poor districts but also that the subsidyat least earmarked school taxes-must be raised on the basis of equalized effort.

\section{Geographical Discrimination}

Several different theories of inequality have been in consideration among the lawyers who have been involved in the litigation concerning various state school finance systems. One theory, espoused by Coons, Clune, and Sugarman ${ }^{77}$ and emphasized in the Serrano opinion, has been a strict theory of wealth discrimination. Another, which has been unsuccessful in two cases that have reached the United States Supreme Court, ${ }^{78}$ is a "needs" theory: each child is constitutionally

76. The complaint filed in Serrano sought to raise this issue explcitly. In the second cause of action, the parent-taxpayer plaintiffs alleged that:

As a direct result of the financing scheme, Plaintiff Parents are required to pay a higher tax rate than taxpayers in many other school districts in order to receive for their children the same or lesser educational opportunities as are afforded to children in these other school districts . . . .

Complaint at 15. The supreme court held that this did state a cause of action, but the opinion escapes whatever difficulty might have been perceived in facing the parenttaxpayers' claim directly. In California, taxpayers' suits are liberally encouraged to prevent the spending of funds by public officials on illegal action. Recently such actions have come to be used as citizens' actions to enjoin any illegal conduct by officials. Quoting from its own recent decision, the court said:

If the ... law is unconstitutional, then county officials may be enjoined

from spending their time carrying out its provisions . . .

5 Cal. $3 \mathrm{~d}$ at 618,487 P.2d at $1265,96 \mathrm{Cal}$. Rptr. at 625 , quoting Blair v. Pitchess, 5 Cal. 3d 258, 269, 486 P.2d 1242, 1249, 96 Cal. Rptr. 42, 49 (1971). Since the plaintiff children had stated a cause of action, the plaintiff parent-taxpayers could properly seek injunctive relief. Thus, there was no need for the court to spenk directly to the substance of these plaintiffs' constitutional claim. But the court's disposition of the plaintiff children's claim necessarily rests on reasoning that vindicates the claim of their taxpaying parents.

77. PrIvate Wealth 338-93; Educational Opportunity 358-71.

78. Burruss v. Wilkerson, 397 U.S. 44 (1970); McInnis v. Ogilvie, 394 U.S. 322 (1969). See text accompanying notes 91-95 infra. 
entitled to state support of education according to his own educational needs. A third theory, advanced by Arthur Wise ${ }^{79}$ as well as Harold Horowitz and Diana Neitring, ${ }^{80}$ stresses the unfairness of wide disparities in educational offerings among various geographical locations within a state. All three theories were included in the Serrano complaint; but, as the case moved toward the California supreme court, the strategy of the litigation favored focusing on the theory of wealth discrimination. ${ }^{81}$ At the oral orgument in Serrano, counsel for the plaintiffs were asked this question: Cannot a district decide to spend more on education than other districts spend, if its residents wish to do so? Counsel replied: That is not this case; we do not need to argue that geographic inequalities are invalid, since there is wealth discrimination in our case; and, if wealth discrimination is eliminated, we do not anticipate the continuation of wide interdistrict disparities in educational spending, so that the hypothetical case may never arise. It seems very nearly certain that if Justice Sullivan had written an opinion that required geographical equality in spending, five justices would not have joined in his opinion. ${ }^{82}$

Yet, the Serrano opinion contains a discussion that, at the very least, leaves the way open for the court to pursue issues of geographical inequality in the future. This discussion is part of the opinion's treatment of the final question in the new equal protection analysis: whether the state's classification scheme is justified as necessary to achieve a compelling state interest. The court's pronouncements on geographical inequality are a response to the defendants' argument that territorial uniformity is not constitutionally required. ${ }^{83}$ The response, which follows the analysis of Horowitz and Neitring, relies upon two lines of United States Supreme Court precedents: the school closing cases $^{84}$ and the reapportionment cases. ${ }^{85}$ These cases are characterized by the Serrano court as standing for the following proposition:

[W] here fundamental rights or suspect classifications are at stake, a

79. A. Wise, Rich Schools, POOR Schools passim (1968).

80. Horowitz \& Neitring, Equal Protection Aspects of Inequalities in Public Education and Public Assistance Programs from Place to Place Within a State, 15 U.C.L.A.L. REv. 787 passim (1968).

81. After the two United States Supreme Court decisions were issued, plaintiffs needed to emphasize a theory that could be distinguished from those rejected.

82. Stephen Goldstein says that this country's history and traditions make it politically impossible to prevent localities from raising local funds to snpplement educational offerings; he explains Serrano's failure to insist on eqnal spending by reference to these traditions. Goldstein, supra note 4, at -

83. 5 Cal. 3d at 611,487 P.2d at 1260, 96 Cal. Rptr. at 620 .

84. E.g., Griffin v. County School Bd., 377 U.S. 218 (1964); Hall v. St. Helena Parish School Bd., 368 U.S. 515 (1962), aff'g mem. 197 F. Supp. 649 (E.D. La. 1961).

85. E.g., Reynolds v. Sims, 377 U.S. 533 (1964). 
state's general freedom to discriminate on a geographical basis will be significantly curtailed by the equal protection clause. ${ }^{80}$

The court concludes:

If a voter's address may not determine the weight to which his ballot is entitled, surely it should not determine the quality of his child's education. ${ }^{87}$

The passage is highly suggestive, because it emphasizes that geographic inequalities in the delivery of educational services to an individual child, as distinguished from inequalities in the financing capacity of school districts, may also be unconstitutional. The child whose education is subordinated to the preferences of his district's adult voters for improved boating facilities is aggrieved no less than the child whose education is diminished because his district is poor. Because education is a fundamental interest, Serrano says, inequities in delivering educational services cannot be justified by the state's interest in decentralized decisionmaking. ${ }^{88}$ It behooves equal protection litigators to keep nourishing this principle, even while they are exploiting Serrano by emphasizing the attack on wealth discrimination.

\section{II}

\section{The California Court as Respectful Subordinate}

In Serrano the California court was writing on a doctrinal page that was almost blank. In these circumstances, it was predictable that the court would treat its relations with the United States Supreme Court with the utmost circumspection. The Serrano opinion relies heavily on analogous new equal protection decisions of the Supreme Court and makes only occasional reference to the California court's own trailblazing on this doctrinal frontier. Nevertheless, Serrano is an original contribution by a state court to the development of federal constitutional law. This phenomenon is not new for the California court: that

86. 5 Cal. $3 \mathrm{~d}$ at 612,487 P.2d at $1261,96 \mathrm{Cal}$. Rptr. at 621 .

87. Id. at 613,487 P.2d at 1262, 96 Cal. Rptr. at 622 . After Serrano was decided, Stephen D. Sugarman and John E. Coons, on behalf of the amici curiae listed in note 36 supra, sent Chief Justice Wright a letter suggesting a modification of the opinion that would make clear the court's rejection of the principle of geographical equality. This letter recommeuded the insertion of this sentence following the one quoted in the text:

Territorial uniformity in the sense of equal spending per pupil is not required; the inequatity here forbidden is that respecting fiscal capacities.

The Court's Modification of Opinion, issued a week later, did not incorporate the suggestion contained in this after-the-fact amicus brieflet.

88. See Michelman, supra note 14, at 50-56; cf. Goldstein, Book Review, 59 CalIF. L. Rev. 302, 306-10 (1971) (effectively criticizing the view that localized decisionmaking can justify disparities in educational offering). See also Silard \& White, Intrastate Inequities in Public Education, 1970 WIs. L. Rev. 7, 29. But see Schoettle, supra note 4, at 1405-18, discussed in text accompanying notes 151-57 infra. 
court has sometimes anticipated the extension of the equal protection doctrine of the Supreme Court ${ }^{5 \theta}$ and has even pressed the doctrine beyond where the Supreme Court was prepared to go. ${ }^{90}$

In view of its relationship to the Supreme Court, two parts of the Serrano court's opinion deserve special mention. First, the court had to deal with the defendants' argument that two recent summary decisions by the Supreme Court in cases dealing with school finance had already decided the issues that the plaintiffs were now presenting for decision. Second, the California court had to decide whether Serrano should be rested on an alternative ground based on state law. Both these aspects of the opinion are of special interest to anyone who would assess the place of the California court in the system of judicial review.

\section{A. School-Finance Precedents of the United States Supreme Court}

In 1968, just three months after the Serrano complaint had been filed, a three-judge federal district court rejected a similar complaint in an action challenging Illinois' school finance system. ${ }^{91}$ The trial judge in Serrano cited the Illinois decision at the time he sustained the defendants' demurrers. ${ }^{92}$ While Serrano was pending in the California court of appeal, the Supreme Court summarily affirmed the Illinois decision without argument and without opinion. ${ }^{33}$ In their briefs and argument to the California supreme court, the defendants in Serrano argued, as the courts below had both held ${ }^{94}$ that McInnis and a similar summary affirmance of a three-judge court's decision in a Virginia

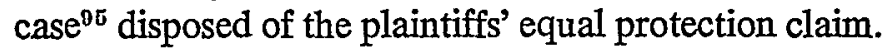

89. E.g., compare In re Antazo, 3 Cal. 3d 100, 473 P.2d 999, 89 Cal. Rptr. 255 and Purdy \& Fitzpatrick v. State, 71 Cal. 2d 566, 456 P.2d 649, 79 Cal. Rptr. 77 (1969) with Tate v. Short, 401 U.S. 395 (1971) and Graham v. Richardson, 403 U.S. 365 (1971).

90. See, e.g., Westbrook v. Mihaly, 2 Cal. 3d 765, 471 P.2d 487, 87 Cal. Rptr. 839 , vacated, 403 U.S. 915 (1971). At this time the California supreme court's monumental decision invalidating capital punishment, People v. Anderson, 6 Cal. 3d 628, 493 P.2d 880, 100 Cal. Rptr. 152 (1972), has no response from the United States Supreme Court. The decision was based on the "cruel or unusual punishment" clause of the California constitution, but Chief Justice Wright's opinion has equal protection overtones.

91. McInnis v. Shapiro, 293 F. Supp. 327 (N.D. Ill. 1968), affd mem. sub nom. McInnis v. Ogilvie, 394 U.S. 322 (1969).

92. The citation appears in the minute order of the trial court sustaining the demurrers. See Serrano v. Priest, 89 Cal. Rptr. 345, 348 n.8 (1970).

93. McInnis v. Ogilvie, 394 U.S. 322 (1969).

94. See note 92 supra.

95. Burruss v. Wilkerson, 397 U.S. 44 (1970), affg mem. 310 F. Supp. 572 (W.D. Va. 1969). Since the three-judge court in this case merely decided on the basis of Mclnnis, the California court addressed its discussion entirely to McInnis. 
The plaintiffs' response was taken from the writings of Coons, Clune, and Sugarman: the McInnis complaint had rested on a different theory, one that asserted public scliool expenditures were constitutionally required to be made on the basis of pupils' educational needs, and this theory was properly rejected for want of manageable judicial standards. In contrast, the Serrano plaintiffs argued that they were asking only for a decision that the state and federal constitutions required fiscal neutrality in the form of the elimination of wealth discrimination among districts. This midlitigation abandonment of a needs theory by the Serrano plaintiffs permitted the Califorma supreme court to conclude that McInnis was not controlling:

[T] he contentions of the plaintiffs here are significantly different from those in McInnis. The instant complaint employs a familiar standard which has guided decisions of both the United States and California Supreme Courts: discrimination on the basis of wealth is an inherently suspect classification which may be justified only on the basis of a compelling state interest. ${ }^{96}$

What is conveniently overlooked in this discussion is that the complaints in the two cases really were not very dissimilar. The Serrano plaintiffs had included a needs theory and a geographical-equality theory along with their theory of wealth discrimination; the McInnis complaint had alleged wide interdistrict disparities in school expenditures, "thereby providing some students with a good education and depriving others, who have equal or greater educational need."107 The McInnis plaintiffs, far from insisting that all school expenditures be made on the basis of a needs test, liad suggested this system as only one alternative that would be constitutional, while recognizing that it would be equally constitutional if all students received the same dollar appropriations. ${ }^{98}$ The McInnis plamtiffs had given considerable emphasis to their needs argument, but it was the three-judge court that gave the case the doctrinal characterization that enabled the court to reject the complaint as insufficient. Equally, it was the California supreme court that gave Serrano its theoretical characterization and thus distinguished McInnis. One is tempted to ask: Whatever became of fact pleading?

McInnis and the later Virginia decision were decisions on the merits, affirming the lower courts' determinations that no constitutional violations had been alleged. The Serrano court, however, realistically recognized that the Supreme Court's decisions in those cases could not be taken as conclusive authority, because the Supreme

96. 5 Cal. 3d at 617, 96 Cal. Rptr. at 624, 487 P.2d at 124.

97. $293 \mathrm{~F}$. Supp. at 329 (the court's paraphrase).

98. Id. at 331-32. 
Court's jurisdiction over an appeal from a three-judge court's decision is obligatory, and therefore the dismissal of an appeal, although technically an adjudication on the merits, is often the equivalent of a denial of certiorari. ${ }^{99}$ Furtliermore, the Supreme Court's liandling of yet another school finance case showed that it did not regard McInnis as the last word on the subject. ${ }^{100}$

Throughout this refreshingly candid discussion, the California court maintained an attitude of deference to the Supreme Court. From beginning to end, the Serrano opinion appears to be an effort to apply established Supreme Court doctrine to a new subject. Yet, throughout the opinion one senses that the California court has recognized the need for a thorough judicial treatment of the constitutional issues in public school finance and also its own opportunity to make a major contribution to the developinent of national constitutional law. ${ }^{101}$ The competing interests in this subject area badly needed judicial articulation, ${ }^{102}$ and the California court properly entered the field the Supreme Court had left vacant.

\section{B. The California Constitution: An Independent State Ground?}

A state supreme court can insulate its analysis of federal constitutional issues from United States Supreme Court review by resting a decision on an alternative and independent ground based on state law. In a number of recent decisions, the California court las extended the domain of the new equal protection beyond previous Supreme Court decisions. Sometimes the Supreme Court agreed with the California court $^{103}$ and once it disagreed. ${ }^{104}$ The California court has occasionally protected its decision from Supreme Court review by nnaking clear that the decision also rests on a state constitutional ground. ${ }^{105}$ In

99. $5 \mathrm{Cal}$. 3d at $616,487 \mathrm{P} .2 \mathrm{~d}$ at $1264,96 \mathrm{Cal}$. Rptr. at 624 , quoting Currie, The Three-Judge District Court in Constitutional Litigation, 32 U. CHr. I. REv. 1, 74 n.365 (1964).

100. Askew v. Hargrave, 401 U.S. 476 (1971) (remanding for the development of a full factual record).

101. It is noteworthy that the opinion first spends some 20 pages discussing the merits of the equal protectiou issues [5 Cal. $3 \mathrm{~d}$ at 597-615, 487 P.2d at 1249-63, 96 Cal. Rptr. at 609-23], and only then turns to Mclnnis for a three-page glance [id. at 615-17, 487 P.2d at 1263-65, 96 Cal. Rptr. at 623-25].

102. See note 100 supra.

103. See note 89 supra.

104. See note 90 supra.

105. E.g., In re King, 3 Cal. 3d 226, 474 P.2d 983, 90 Cal. Rptr. 15 (1970), cert. denied, 403 U.S. 931 (1971). In People v. Anderson, 6 Cal. 3d 628, 493 P.2d 880, $100 \mathrm{Cal}$. Rptr. 152 (1972), the California court seemed determined to insulate its decision invalidating capital punishment from Supreme Court review. The decision was rested exclusively on the state constitution. In contrast, in another post-Serrano decision, holding invahi a statutory "one-dollar-one-vote" system that allocated voting strength in municipal improvemeut districts to property owners according to the assessed valuation of their land, the decision was rested exclusively on the fourteenth 
Serrano the plaintiffs offered the California court just such an opportunity. They argued that the school finance system violated not only the fourteenth amendment's equal protection clause but also several provisions of the state constitution. Two of those provisions are analogous to the equal protection clause: they require that "general" laws have "a uniform operation,"106 and that "privileges and immunities" granted to some citizens be granted to all citizens. ${ }^{107}$ A third state constitutional provision relied on by the Serrano plaintiffs requires the legislature to provide for "a system of common schools."108

Where the challenged state law is itself a part of the state constitution, it is not possible for the decision to be so insulated from Supreme Court review of the federal constitutional issues, for there is no opportunity to rest a decision on alternate state grounds. ${ }^{100}$ The school finance system in California is partly constitutional and partly statutory. Article IX, the education article containing the "common schools" provision the Serrano plaintiffs relied upon, also provides the basic authority for the creation by the legislature of local school distriets, authorizes local district taxation to support the public schools, and sets out certain minimum annual state contributions to local school districts. $^{110}$ Statutory law provides for state support for local districts through annual "flat grants" of $\$ 125$ per pupil and annual "equalizing grants." ditional revenues through taxation of property in the district. ${ }^{112}$

The Serrano court rejected the argument based on article IX, section 5, the "common schools" provision. This provision, said the court, had always been interpreted to require only that the system of instruction be uniform throughout the state. ${ }^{113}$ Furthermore, the court noted that the next section of article IX "specifically authorizes the very element of the fiscal system of which plaintiffs complain,"114 and the general language of section 5 cannot reasonably be construed

amendment. Burrey v. Embarcadero Municipal Improvement Dist., 5 Cal. 3d 671, 488 P.2d 395, 97 Cal. Rptr. 203 (1971).

106. CaC. Const. art. I, $\$ 11$.

107. Id. art. $\mathrm{I}, \$ 21$.

108. Id. art. IX, §5.

109. See, e.g., Castro v. California, 2 Cal. 3d 223, 466 P.2d 244, 85 Cal. Rptr. 20 (1970); Mulkey v. Reitman, 64 Cal. 2d 529, 413 P.2d 825, 50 Cal. Rptr. 881 (1966), aff'd, 387 U.S. 369 (1967).

110. Cal. ConsT. art. IX, $\S \S 5,6,61 / 2,7,14$.

111. Cax. Educ. Code ANN. $\$ \$ 17651-80,17702,17901-02$ (West 1969) (districts that agree to tax their property at certain minimum rates are paid the difference between (a) $\$ 125$ plus the amount per pupil raised by local taxation, and (b) $\$ 355$ per elementary school pupil or $\$ 488$ per high school pupil).

112. Id. \$§ 20751-51.1, 20803.

113. See Piper v. Big Pine School Dist., 193 Cal. 664, 226 P. 926 (1924).

114. 5 Cal. 3d at 596, 487 P.2d at 1249, 96 Cal. Rptr. at 609. 
to control the more specific and more recently adopted provisions in the next section.

In the next paragraph of its opinion, the court turned to the plaintiffs" equal protection claim. Its entire discussion of the state "equal protection" provisions is contained in this footnote:

The complaint also alleges that the financing system violates ... [the equal protection provisions] of the California Constitution. ... We have construed these provisions as "substantially the equivalent" of the equal protection clause of the Fourteenth Amendment to the federal Constitution. (Dept. of Mental Hygiene v. Kirchner (1965) . ... Consequently, our analysis of plaintiffs' federal equal protection contention is also applicable to their claim under these state constitutional provisions. ${ }^{115}$

The juxtaposition of these two passages of the opinion invites the question: If the "common schools" provision of section 5 of article IX must be read in conjunction with the more specific and later adopted school finance provisions of section 6 , why should not the state "equal protection" clauses be similarly read? Section 6 of article IX was adopted after these provisions as well: it was enacted in 1920, while the state "equal protection" provisions of article I were part of the original 1879 constitution. Thus, there is an apparent logical obstacle to a determination that Serrano rests on an independent state ground. This obstacle, however, is only apparent. The "system" held unconstitutional in Serrano is not local district taxation as such, which is what is authorized in the state constitution, but the statutory implementation of this authorization. Statutes provide the mechanism for defining the school district lines and authorize the zoning laws and other land-use controls that produce great disparities in district real property wealth. The statutory flat grant prograin, combined with the statutory equalization grants, accentuates these disparities. ${ }^{116}$

A more serious difficulty is presented by the California court's comment that the state constitution's "uniform laws" and "equal privileges" provisions are the substantial equivalent of the federal equal

115. Id. at $596 \mathrm{n} .11,487$ P.2d at 1249 n.11, 96 Cal. Rptr. at 609 n.11.

116. See Brief of Stephen D. Sugarman, The Urban Coalition, The National Committee for the Support of the Public Schools, and John E. Coons as Amici Curiae at 7-8. For one statutory scheme that would implement article IX, section 6, without imposing wealth discrimination, see Prrvate Wealth 201-42. In essence, the authors propose a system that would permit a school district to spend any amount it wished to spend on public schools, perhaps with a per-pupil maximum level of spending, merely by adopting a school tax rate that was pegged to a given level of spending. Thus a $21 / 2$ percent rate might produce a spending capacity of $\$ 500$ per pupil, a 4 percent rate, $\$ 800$, a 6 percent rate, $\$ 1,200$. State funds would collect excess tax revenues and distribute them along with additionally needed state funds to poor districts that "earned" outside aid by paying high enough tax rates. See text accompanying note 160 infra. 
protection clause. It is not unusual for a state court to rely on both federal and state constitutional provisions in striking down state legislation and even to intermix discussion of both provisions. The language of the two constitutions may be closely similar, as in the case of some state due process clauses; and even when the constitutions are not cast in the same words, it is natural for a state court to be influenced in its interpretation of a state constitutional provision by the Supreme Court's treatment of an analogous provision in the United States Constitution. The question to be asked in such a case is whether the state court has "felt constramed to rule as it did"117 because of the Supreine Court's interpretation of the federal Constitution, or whether the state constitutional ground rehed on by the state court is, in its judgment, truly independent. In the latter event, the Supreme Court will not review the state court's decision, because the Court has equated such review with the rendering of an advisory opinion. $^{118}$ Thus, the question is whether the California supreme court mdicated that it would still reach the same decision on the basis of the state constitutional provisions cited even if the United States Supreme Court were to determine that the plaintiffs' federal constitutional claim is groundless.

The answer is affirmative, although there is no doubt that the court could have been more explicit. The key is the citation to the Kirchner case ${ }^{119}$ in the footnote. In that case, the California court had held invalid a state statute that made persons liable for the cost of supporting certaim relatives who were inmates in state mental institutions. The court's opinion said merely that the statute violated "the basic constitutional guaranty of equal protection of the law . . .."120 The Supreme Court granted certiorari, but remanded the case for clarification of the grounds for its decision. ${ }^{121}$ On remand, the California court reaffirmed its decision, this time explicitly resting it imdependently on the state constitution's uniform-laws and equal-privileges

117. Minnesota v. National Tea Co., 309 U.S. 551, 555 (1940).

118. Herb v. Pitcairn, 324 U.S. 117, 125-26 (1945). It makes no difference that the relevant federal and state constitutional provisions are cast in identical words [New York City v. Central Sav. Bank, 306 U.S. 661 (1939), denying cert. to 280 N.Y. 9, 19 N.E.2d 659 (1939)], that the state court has construed other language in the state constitution to inean virtually the same thing as similar provisions of the federal constitution [Jankovich v. Indiana Toll Road Comm'n, 379 U.S. 497 (1965); Minnesota v. National Tea Co., 309 U.S. 551 (1940)], or that the state court's discussion blurs the two grounds together [Jankovich v. Indiana Toll Road Coının'n, stupra, Minresota v. National Tea Co., supra].

119. Department of Mental Hygiene v. Kirchner, 60 Cal, 2d 716, 388 P.2d 720, 36 Cal. Rptr. 488, vacated and remanded, 380 U.S. 194 (1965).

120. Id. at 717, 388 P.2d at 720, 36 Cal. Rptr. at 488.

121. 380 U.S. at 204. 
clauses. ${ }^{122}$ After stating that these provisions are "substantially the equivalent" of the federal equal protection clause-the phrase quoted in the Serrano footnote- - the court went on to say:

While it is our view that we should reach the same conclusion under the Fourteenth Amendment we were (and we are) in any event independently constramed to the result we reached by sections 11 and 21, article I, of the California Constitution. We so conclude by our construction and application of California law, regardless of whether there is or is not compulsion to the same end by the federal Constitution. ${ }^{123}$

Thus, the Serrano court's reference to this page of its Kirchner opinion is an indirect indication that the California school finance system violates the state constitution as well as the equal protection clause. ${ }^{124}$

This conclusion may seem shaky, since the entire text of the Serrano opinion is devoted exclusively to discussion of the plaintiffs' federal constitutional claim. But considerations of style alone might dictate such an approach. The court's state law footnote declares that the textual analysis of the federal claim applies equally to the state constitutional issue. It would have been ridiculously cumbersome for the court to have repeated at every point in the opinion where reference is made to the equal protection clause, "and article I, sections 11 and 21 of the California Constitution." Alternatively, the court may have felt that since the Serrano judgment was not yet final, it did not yet have to be explicit about the state constitutional question, because the United States Supreme Court reviews only final judgments. ${ }^{125}$ The state law

122. Department of Mental Hygiene v. Kirchner, 62 Cal. 2d 586, 588, 400 P.2d 321, 322, 43 Cal. Rptr. 329, 330 (1965).

123. Id. at 588,400 P.2d at 322,43 Cal. Rptr. at 330 .

124. Furthermore, the Supreme Court is apt to approach the independent state ground question in this case with a presumption against hearing the case. This is not a case in which the denial of a federal constitutional right is masked under a state law ground. See generally Hill, The Inadequate State Ground, 65 CouUM. L. REv. 943 (1965); Sandalow, Henry v. Mississippi and the Adequate State Ground, 1965 Sur. CT. REv. 187. Instead, it is a case in which the state court upheld the asserted claim of a federal right. Until 1914 the Supreme Court had no jurisdiction to hear such a case. See generally C. WRIGHT, HANDBOOK of tHE LAW of Federal COURTS 482 (2d ed. 1970). While the pre-1914 rule may have had the unfortunate consequence of permitting state courts to strike down state laws on the basis of unreviewable interpretations of the federal Constitution, it reflected a system of jurisdictional priorities that still has merit: The highest priority for exercise of the Supreme Court's appellate jurisdiction in cases coming from the state courts is the maintenance of the supremacy of federal law, not the maintenance of uniformity of decision. Although modern decisions on the mdependent state ground issue do not explicitly discuss this ordering of priorities, they are entirely consistent with it. E.g., compare Minnesota v. National Tea Co., 309 U.S. 551 (1940) with NAACP v. Alabama, 357 U.S. 449 (1958).

125. One exception, which might have been inportant in Serrano, is that a nonfinal judgment is reviewable if further proceedings would be only a formality. See Mills v. Alabama, 384 U.S. 214, 217-18 (1966). Pursuant to this rule, the Serrano 
footnote thus might have been added to signal the legislature that even if the federal equal protection ground is ultinately rejected by the Supreme Court, the decision will remain the same. Or the reason why this aspect of the decision was incongruously left less than explicit in the midst of so careful an opinion may be that the anbiguity in the footnote was intentionally created in order to allow the United States Supreme Court either to decide or not to decide the federal constitutional issues, as it might choose, without announcing what the California court would do in the event that the Supreme Court should disagree as to the federal equal protection issue.

This last view is unpersuasive for two reasons. First, reading the court's state law reference to be calculated in its ambiguity would be inconsistent with the citation to Kirchner. That citation is at the very least a clear statement that the California court is cognizant of the independent-state-ground issue. Furthermore, the citation calls attention to Kirchner's unambiguous declaration that, while the state constitution's equal protection provisions are the substantial equivalent of the equal protection clause of the fourteenth amendment, the state provisions have an independent force of their own. The Kirchner citation takes on added significance when it is remembered that the United States Supreme Court, in that very case, had pronounced that it would have jurisdiction to review "only if the federal ground had been the sole basis for the decision" of the state court. ${ }^{126}$ It was the Supreme Court's doubt on this question that led it to remand the Kirchner case for the clarification that the California court dutifully provided.

A second, and more important, reason for rejecting the notion that the California court's state law pronouncement was intentionally ambignous is that such a reading is imconsistent with the court's assumption of responsibility in facing the doctrinal issues raised by Serrano. If the California court devoted the text of its opinion to exhaustive analysis of the Supreme Court's decisions, with only occasional references to its own equal protection decisions, it surely did so in order to emphasize its role as respectful subordinate, and to deemphasize its own doctrinal leadership. It would not be the first time. ${ }^{127}$

defendants might have conceded the only factual issue remaining for trial [see text accompanying notes 128-47 infra] so that Supreme Court review would rest on the independent state ground issue.

126. Department of Mental Hygiene v. Kirchner, 380 U.S. 194, 198 (1965).

127. See, e.g., Purdy \& Fitzpatrick v. State, 71 Cal. 2d 566, 578-86, 456 P.2d 645, 653-58, 79 Cal. Rptr. 77, 85-90 (1966). Another case in which the California court offered leadership was Mulkey v. Reitman, 64 Cal. 2d 529, 413 P.2d 825, 50 Cal. Rptr. 881 (1966), aff'd, 387 U.S. 369 (1967). The California court's leadership in Mulkey surely was not doctrinal; see the criticism in Horowitz \& Karst, The Proposition Fourteen Cases: Justice in Search of a Justification, 14 U.C.L.A.L. REv. 37 (1966). Yet when the Supreme Court came to review the case, it purported merely to follow the California court's lead. See Karst \& Horowitz, supra note 62, at 40-55. 


\section{III \\ The California Court as Taskmaster}

The Serrano opinion is, of course, not a document addressed exclusively to the Supreme Court; the California supreme court must consider many others in writing such an opinion. The litigants and the lower courts will look to the opinion for guidance, as will the legislature. This final section considers the Serrano opinion's import for these other audiences.

\section{A. The Issue on Remand}

Much that might have been the subject of proof was judicially noticed by the court. ${ }^{128}$ Only one issue is identified in the Serrano opinion as a triable issue: whether different levels of educational expenditure do or do not affect the quality of education. ${ }^{129}$ This complex issue could hardly have been resolved by judicial notice, for it is the subject of deep and continuing disagreement among social scientists. ${ }^{130}$ Given the uncertain state of the social science evidence, it is not surprising that some writers have already concluded that it is highly doubtful that the Serrano plaintiffs will be able to prove their factual case at trial. ${ }^{131}$

The relation of dollars to the educational process is a question of enormous importance to the future of education, deserving of its current high priority among social science issues. As a constitutional problem, however, there is less here than meets the eye. Throughout the era of "separate but equal," courts simply assumed that one good index of inequality was a differential level of expenditure. ${ }^{132}$ In Sweatt $v$. Painter, ${ }^{133}$ the one case in which the United States Supreme

128. The court took judicial notice of all manner of data in the publications of state officers and agencies, such as interdistrict variations in property tax base, the relation of average daily scliool attendance to enrollment, the proportions of school revenues obtained from various sources, and imterdistrict variations in per-pupil school expenditures. See $5 \mathrm{Cal}$. 3d at 591-95, 487 P.2d at 1245-48, $96 \mathrm{Cal}$. Rptr. at 605-08. The court also eliminated a possible triable issue by holding district wealth, not resident wealth, to be the relevant factor. See note 42 supra and accompanying text.

129. See 5 Cal. 3d at 601 n.16, 487 P.2d at 1253 n.16, 96 Cal. Rptr. at 613 n.16.

130. In the same footnote cited in note 129 supra, the court cited two leading studies reaching opposing views: $J$. Coleman, et al., EQuality of Educatronal OpPoRTuNITY (1966); J. GUTHRIE, G. KLEINDORFER, H. LEVIN \& R. STOUT, Schools AND INEQUAITIY (1971). See also the social science material cited in PRIVATE WEALTH 25-33.

131. Goldstein, supra note 4, at -; Schoettle, supra note 4, at 1404.

132. See Horowitz, Unseparate and Unequal--The Emerging Fourteenth Amendment Issue in Public Education, 13 U.C.L.A.L. Rev. 1147, 1149 (1966). Judge Wright relied in part on this article's analysis in Hobson v. Hansen, 269 F. Supp. 401, 496 n.164 (1967), aff'd as modified sub nom. Smuck v. Hobson, 408 F.2d 175 (D.C. Cir. 1969).

133. 339 U.S. 629 (1950). 
Court took a hard look at such questions, it concluded that Texas had provided a law school for black students that was inferior to the University of Texas Law School, for the following reasons, which are, for the most part, directly related to money: number of the faculty, variety of courses and opportunity for specialization, size of the student body, scope of the library, reputation of the faculty, experience of the administration, position and imfluence of the alumni, standing in the community, traditions, and prestige. ${ }^{134}$ Without identifying any specific effects of these inequalities on the educational proces, the Court concluded that the inequalities affected education: "It is difficult to believe that one who had a free choice between these law schools would consider the question close."135 After Brown $v$. Board of Education ${ }^{136}$ courts have continued to assume that differential spending is a good index of imequality; the Serrano court itself went to the verge of doing so, quoting with apparent approval from a number of recent judicial opinions supporting the assumption. ${ }^{137}$

The reasonableness of this commonsense approach can be demonstrated by an example. Suppose that the financing of California's schools were to be accomplished entirely froin state funds and the state were to allocate annually $\$ 600$ per high school student to some school districts and $\$ 1,200$ per high school student to other districts. In the absencê of soine showimg of differential need for such allocations, ${ }^{138}$ that fimancing scheme would certainly be held unconstitutional, even without any demonstration that achievement scores are adversely affected by reduced spending. ${ }^{130}$ Intangible qualities such as a school's prestige and standing in the community are not unrelated to dollars, even if the dollars are spent mainly on the hiring of more teachers or teachers with greater experience. Moreover, in the hypothetical case the differential itself is an insult. If a wealthy district can afford an astronomical observatory and a poor district cannot, the luxury itein in the wealthy school may make little difference to achieveinent test scores. But it will stand as a continuing reminder to the students in the adjoming poor high school that society does not think their aspirations should reach so high. In the separate-but-equal era, after all,

134. Id. at 633-34.

135. Id. at 634 .

136. 347 U.S. 483 (1954).

137. 5 Cal. 3d at 601 n.16, 487 P.2d at 1253 n.16, 96 Cal. Rptr. at 613 n.16.

138. Serrano is entirely consistent with differential spending for such things as compensatory education, the meeting of differential costs owing to variations in locality, or even "lighthouse schools" that set standards for the rest. "In rethinking school finance," suggests Harold Howe, "perhaps ways can be devised to put the lighthouses in Watts and Harlem instead of Beverly Hills and Scarsdale." Howe, Anatomy of a Revolution, SATURDAY Rev. 84, 95 (Nov. 20, 1971).

139. See text accompanying note 51 supra. 
school boards sometimes argued that the schools set aside for blacks offered some courses that were not available at the white schoolssuch as bricklaying. ${ }^{140}$

Although there is irony in the picture of the Serrano defendants, all members of the public education establishment, solemnly denymg in court that the size of their annual budget makes any difference to the quality of education, it now appears likely that they will do precisely that. ${ }^{141}$ The trial court must determine how to allocate the burden of proof on this factual issue. In Hobson $v$. Hansen, ${ }^{142}$ Judge Wright held that where black plaintiffs asserted they were denied equal educational resources within a single district, a showing of disparities in pupil-teacher ratios, average teacher costs, and per-pupil teacher expenditures constituted a prima facie case for the plaintiffs, and placed the burden on the school administrators to rebut the inference of inequality of educational opportunity. ${ }^{143}$ Judge Wright's solution not only accords with the view of the United States Supreme Court, ${ }^{144}$ but also makes sense. Disparities in governmental allocations of resources that are wholly lacking in justification are unconstitutional, ${ }^{\mathbf{1 4 5}}$ and once a substantial disparity is shown, it is appropriate for government to be required to justify it.

The shifting of the burden of proof to the defendants once substantial differentials in spending are shown is also supported by an idea that will surely die hard in this market-oriented country: you get what you pay for. Education is not likely to be assumed to be an ex-

140. See, e.g., Carter v. School Bd. of Arlington County, 182 F.2d 531 (4th Cir. 1950). In this case, not only did the black school offer bricklaying, but it also had hoine economic facilities superior to those of the white school. For an interesting comparison of the symbolisin of inferiority in cases of race and wealth distinctions, see Note, The Evolution of Equal Protection, supra note 4, at 130-38.

141. At this writing, the Serrano defendants have not yet filed an answer. However, the attorney general's decision not to seek review in the United States Supreme Court [L.A. Times, Dec. 31, 1971, part I, at 3, col. 4] suggests the prediction made in the text.

142. 327 F. Supp. 844 (D.D.C. 1971).

143. Goldstein, supra note 4 , at - , says that this burden-of-proof approach is not satisfying when the issue is one of judicial invalidation of a longstanding method of financing public schools. The approach does, however, have respectable ancestry in the theory that racial discrimination, once shown, produces an inversion in the usual presumption of constitutionality, requiring the state to justify the discrimination. See Pollak, Racial Discrimination and Judicial Integrity, 108 U. PA. L. Rev. 1 (1959).

144. Sweatt v. Painter is not the only Supreme Court pronounceinent on this issue. In Gaston County v. United States, 395 U.S. 285 (1969), the Court held that a "neutral" literacy test had the effect of a racially discriminatory denial of the right to vote, because of the county's past inaintenance of "separate and inferior schools for its Negro residents." Id. at 293. The inferiority of the black schools was found to rest on such things as differential salary levels for teachers and differential per-pupil values of the physical plants.

145. See text accoinpanying note 51 supra. 
ception to that idea either by courts or by anyone else when there is so little agreement on other measures of educational quality. If money makes no difference to educational quality, then it is hard to understand the concern Serrano has caused in California's wealthy school districts. ${ }^{146}$ Coons, Clune, and Sugarman make this commonsense point nicely: "If money is madequate to improve education, the residents of poor districts should at least have an equal opportumity to be disappointed by its failure."147

\section{B. The Court and the Legislature}

One reason Serrano caused so little political outcry is undoubtedly that the residents of wealthy districts cannot yet gauge the decision's financial impact on them and on their schools. Another reason is that the immediate political effect of this decision, unlike that of many another decision holding legislation unconstitutional, is not so much to limit the legislature as to liberate it; Serrano pries the legislative flywheel off dead center and creates legislative options that existed before only in theory. ${ }^{148} \mathrm{~A}$ new legislative alliance, teaming poor districts with districts that are neither poor nor wealthy but whose residents now sense the possibility of tax reform, seems likely to ennerge. ${ }^{140}$ Serrano is thus a textbook case of the new equal protection doctrine: judicial intervention on behalf of a disadvantaged group. ${ }^{\mathbf{1 5 0}}$

Thus, the principal criticism of Serrano has appeared not in political speeches but in the law reviews. Ferdinand Schoettle concludes his long, thoughtful treatment of the school-finance problem by arguing that the Serrano court reached the right result for the wrong reason. ${ }^{151} \mathrm{He}$ rejects the court's implicit adoption of the proposition of Coons, Clune, and Sugarman that "the quality of public education nay not be the function of wealth other than the wealth of the state as a whole."152 The main fault in this formula, Professor Schoettle argues, is that it treats school fimancing in isolation rather than as part

146. See L.A. Times, Sept. 2, 1971, part VII, at 1, col. 1.

147. Private Wealth 30.

148. The great decision in Gibbons v. Ogden, 22 U.S. (9 Wheat.) 1 (1824), was just such a deeision, freeing the state's legislature froin an unwanted steamboat monopoly that was arguably beyond legislative undoing because of the contract clause.

149. See Private Wealth 454.

150. See Hobson v. Hansen, 269 F. Supp. 401, 507-08 (1967), aff'd as modified sub nom. Smuck v. Hobson, 408 F.2d 175 (D.C. Cir. 1969).

151. Schoettle, supra note 4, at 1405-12. Harold Horowitz and I made the same sort of comment about Reitman v. Mulkey [see note 62 supra]; Herbert Wechsler said the same of Brown v. Board of Education [see Toward Neutral Principles of Constitutional Law, 73 HARv. L. REv. 1, 31-34 (1959)]. It is a pity that there were no contemporary academic critics to correct the opinion in Marbury v. Madison.

152. Private Wealth 34; Educational Opportunity 311. 
of the total budgetary process. Disparities in local tax base affect the capacity of a local district to finance all the services of local government, not inerely schools.

Professor Schoettle's argument is not simply an assertion that Serrano's wealth discrimination reasoning must be extended to other public services. It rests, instead, on a conception of the judicial function that is far more modest. Judges, he says, are incapable of inaking the allocations of public resources that are at the heart of the budgetary process. Sucl resource-allocation decisions cannot be inade on principle, but inust be left to the discretionary processes of legislation. ${ }^{163}$ Yet Professor Schoettle's own proposed constitutional standard is itself neo-Coonsian: a state cannot "perpetuate substantial interdistrict inequalities in the resources that are available to each voter for allocation by means of the public budget." ${ }^{154}$ The point would be to provide equality among districts in their total resources for public services, and to allow each district's voters the freedom to choose how much of those funds should be allocated to education and how much to welfare assistance, fire and police protection, samitation, and all the other services that compete with schools in the budgetary processes of local government. The point is close to the argument of the taxpayer plaintiffs in Serrano. ${ }^{155}$

Suppose California were to adopt Professor Schoettle's forinula, redistricting in such a way as to equalize each district's per-capita tax base. In that event, the large cities would spend less for education than would the suburbs, for the cities would have no choice but to allocate a greater proportion of their resources to other public services. ${ }^{156}$ This problein of nunicipal overburden cannot be resolved by assuring per-capita equality of district tax bases. If the state is serious about equality of educational opportunity, it will supplement the budgets of the overburdened urban districts to assure them a budgetary freedoin of choice that is real. And if the judiciary is serious about the

153. Michelman correctly identifies the issue of judicial role as critical to the application of the theory of minimum protection. Michelman, supra note 14, at 56-59. Similar concerns about the limits of judicial competence in Serrano-style situations are expressed in Kurland, Equal Educational Opportunity: The Limits of Constitutional Jurisprudence Undefined, 35 U. CHI. L. Rev. 583 (1968).

154. Schoettle, supra note 4, at 1418-19. Consolidation of wealthy and poor districts would be a useful device for satisfying this formula. For a discussion of the current status of litigation aimed at achieving racial integration through metropolitan consolidation of school districts, see Taylor, Metro Plans Can Work; Richmond May Show How, 3 South Today, no. 6, at 4 (Jan.-Feb. 1972).

155. See text following note 38 supra. The Serrano court's analysis of unequal tax efforts approaches acceptance of Professor Schoettle's position. See text accompanying note 74 supra.

156. Professor Schoettle recognizes the problem of municipal overburden. See Schoettle, supra note 4, at 1410. 
guarantee of equal protection of the laws, courts will require the state to provide such supplements.

We thus come full circle to the doctrimes of the new equal protection. If the state has a constitutional obligation to equalize its local districts' freedom of choice to spend for education, the reason is that courts have identified education as a fundamental interest or a "just want." Short of abdication, there is no escape from judicial selection of priorities from among the infinity of goods and services that might be sought by those who lack them. Education plaimly ranks high on the pubhic's list of priorities; school districts that can afford to spend freely for schools are doing so, while poorer districts are straining their fiscal capacities to the same end. Whatever the social scientists' doubts, ${ }^{157}$ the judicary is on sound political ground when it holds, as the Serrano court did, that education is a fundamental interest.

The Serrano opinion avoided suggesting any alternative school finance system and the oinission was deliberate. The Los Angeles Tinies quoted "a court source"-perhaps one of the justices-who coinmented that the decision "appeared to leave the solution up to the Legislature."158 Far from hurling a challenge at the legislature, the court sought to minimize friction, both im the timing of its decision and in its instructions relating to the timing of possible remedies. ${ }^{160}$ The legislative response is not yet clear, but it seems virtually certain that changes will be made in both the taxing and distribution aspects of the school fimance system. To some significant extent, statewide taxation will replace local taxation as a revenue source for the schools, and the per-pupil distribution of funds to school districts will be significantly equalized. It would be surprising if the legislature were to move immediately to a system of equal per-pupil spending, financed by taxes based on ability to pay. Most observers expect the legislative response to fall short of both those standards of equality.

"District power equalizing," in which each district can, by levying taxes at various prescribed levels, draw on state funds in order to be able to spend at certain levels of per-pupil expenditure, ${ }^{100}$ would al-

157. See the review of the literature in $i d$. at 1378-88.

158. L.A. Times, Aug. 31, 1971, pt. 1, at 1, col. 5.

159. The Serrano decision had been pending for many months when it finally came down; other cases argued around the same time had long since been decided. The court surely was waiting until the legislature and the governor had completed their annual budget ballet. Furthermore, some two months after its decision, the Serrano court issued a memorandum modifying its opinion, adding this language:

Obviously, any judginent invalidating the existing system of public school financing should make clear that the existing system is to remain operable until an appropriate new system, which is not violative of equal protection of the laws, can be put into effect.

160. See note 116 supra. 
most certainly pass the Serrano test of constitutionality, ${ }^{161}$ but the scheme's complexity and the unpredictability of the state's annual obligation makes it an improbable early choice of the legislature. More likely, there simply will be an effort to imcrease substantially the state's contribution to local districts. Such a scheme, like the family voucher proposal, ${ }^{162}$ will surely leave some wealth discrimination in the system. If the state's contribution, either to districts or to families, is not a very substantial one, the California supreme court seems sure to conclude that the new system is only a whitewashed version of the old. While some mequalities will be tolerated once all schools are receiving high levels of per-pupil expenditure, those imequalities must not touch features of the educational process that the court will characterize as fundamental. ${ }^{163}$

Serrano inescapably means some substantial degree of leveling. Either "leveling down" or "leveling up" will be unpopular with the residents of wealthy districts, because either expenditures for their children's schools will decline or their taxes will go up. To the beneficiaries of Serrano, however, this leveling will seem a matter of simple justice, long overdue. But casting the issue in these terms falsely suggests that the school fimance system is merely a zero-sum game, in which a poor district's gain is mevitably a rich district's loss. The Serrano court properly rejected this view; in its discussion of education as a fundamental interest, it stressed the value of education not only to the child, but also to society. Another apparent response was the court's closing quotation from Horace Mann, who found in natural law

161. This scheme would not, however, pass a test of geographical equality. See text accompanying notes 77-88 supra. See also the criticism of district power equalizing in Brest, supra note 52, at 594-97; Goldstein, supra note 4, at -.

162. By this term I mean merely a system that makes flat per-pupil grants to families in the form of vouclers that can be spent at approved schools, public or private. For a family choice system that goes a considerable distance toward removing wealth discrimination, see Coons \& Sugarman, Family Choice in Education: A Model State System for Vouchers, 59 CaLIF. L. Rev. 321 (1971). The authors' model statute, an extraordimarily useful example of the art of the lawyer-reformer, establishes a system of "family power equalizing." In this system, the state provides a minimum level of per-pupil spending; beyond that level, families are permitted to choose to draw on state funds for increasingly greater amounts of school expenditure, by electing to be taxed at increasingly higher rates on their family incomes:

Accordingly, each family's selection of a school from among schools of varying per pupil cost would represent also a choice among varying rates of a special tax to be levied upon the family's income; but the tax burden of families of different incomes choosing schools of the same per pupil cost would, in economic terms, be rendered equivalent by means of a progressive rate structure.

Id. at 331 .

163. See text accompanying notes $20,57-71$ supra. 
a principle antecedent to all human institutions, and incapable of being abrogated by any ordinance of man ... which proves the $a b$ solute right to an education of every human being that comes into the world, and which, of course, proves the correlative duty of every government to see that the means of that education are provided for all. ${ }^{164}$

The court can be pardoned for concluding an opinion of such distinction and national significance on a rhetorical up-beat. But the best response to the "haves" who are reluctant to share with "have-nots" is less of a deduction from natural law principles and more of a practical judgment about our society's common needs. The point is captured nicely in a letter written to the Los Angeles Times by Mr. Robert L. Porter, a citizen of Orange County:

We need all the bright kids we can get, so don't make it a requirement that they have not only brains, but a rich dad too. ${ }^{165}$

164. $5 \mathrm{Cal} .3 \mathrm{~d}$ at $618,487 \mathrm{P} .2 \mathrm{~d}$ at 1266, $96 \mathrm{Cal}$. Rptr. at 626, quoting Old South Leaflets V, No. 109 at 177-80 (1946) (10th Annual Rep. to Mass. State Bd. of Educ.), quoted in READINGS IN AMERICAN EDUCATION 336 (1963).

165. L.A. Times, Oct. 9, 1971, Part II, at 4, col. 6. 